\title{
Alternative lengthening of telomeres in the human adrenocortical carcinoma cell line H295R
}

\author{
MASACHIKA FUJIWARA ${ }^{1}$, HIROSHI KAMMA ${ }^{2,4}$, WENWEN WU ${ }^{2}$, YUKIKO YANO ${ }^{2,3}$, \\ SHINSUKE HOMMA ${ }^{2,3}$ and HIROAKI SATOH ${ }^{3}$ \\ ${ }^{1}$ Department of Pathology, Kensei General Hospital, Iwase, Nishi-Ibaraki, Ibaraki 309-1295; \\ ${ }^{2}$ Institute of Basic Medical Sciences and ${ }^{3}$ Institute of Clinical Medicine, \\ University of Tsukuba, Tsukuba, Ibaraki 305-8575, Japan
}

Received May 18, 2004; Accepted October 12, 2004

\begin{abstract}
Telomere maintenance can occur in the absence of telomerase by a mechanism referred to as alternative lengthening of telomeres (ALT). ALT is considered to be rare in tumors of epithelial origin. The biological significance and molecular mechanism of ALT have not been well studied in human cancers. It has been reported that clinical samples of adrenocortical carcinoma show a low incidence of telomerase positivity. We characterized an adrenocortical carcinoma cell line, H295R, focusing on the telomere maintenance mechanism, and compared it with telomerasepositive 293 cells and HeLa cells. Telomerase activity could not be detected in H295R cells by the TRAP assay. Among the essential components of the telomerase holoenzyme, only hTERT expression was undetectable by RT-PCR, indicating that the lack of telomerase activity is due to suppression of hTERT. H295R cells had long and heterogeneous telomere DNA, and FISH revealed large nuclear bodies in a few interphase nuclei, which presumably represented ALT-associated PML bodies. These results suggest that H295R cells have the ALT phenotype. Several proteins that are possibly associated with the telomere maintenance mechanism were examined. TRF1 and TRF2 were expressed in H295R cells as well as in 293 cells and HeLa cells. The ratio of hnRNP B1 to A2 was higher in H295R cells than in 293 cells and HeLa cells. In conclusion, the H295R adrenocortical carcinoma cell line is negative for telomerase and maintains its telomeres by the ALT mechanism. We anticipate that H295R cells will be a good model for understanding the significance and mechanism of ALT in human cancers.
\end{abstract}

Correspondence to: Dr Hiroshi Kamma, Present address: ${ }^{4}$ Department of Pathology, Kyorin University, School of Medicine, 6-20-2 Shinkawa, Mitaka, Tokyo 181-8611, Japan

E-mail: hkamma@kyorin-u.ac.jp

Key words: telomere, ALT, adrenocortical carcinoma, H295R

\section{Introduction}

Prevention of telomeric shortening is essential for cancer cells or in vitro immortalized cells, because telomere repeats are lost during DNA replication every time cells divide (1). Most human cancer cells maintain their telomere length by the actions of the ribonucleoprotein enzyme telomerase, which synthesizes telomere repeats using the internal template RNA (hTR) (2). Telomerase inhibitors, therefore, have been believed to hold considerable promise for anticancer treatment. However, the situation becomes somewhat complicated, because several studies have demonstrated that telomere maintenance can occur in the absence of telomerase activity by a mechanism referred to as alternative lengthening of telomeres (ALT) (reviewed in refs. 3,4). Cancer cells with ALT may be resistant to anticancer treatment with telomerase inhibitors. However, the biological significance and mechanism of ALT in human cancers are not fully understood, because most reported ALT cell lines are in vitro immortalized cells derived from mesenchymal cells. Few well characterized ALT cell lines have been established from human cancers.

The ALT phenomenon in vivo is likely to be specific to some tissue or cell types, although extensive surveys for ALT in human tumors have not been carried out. Among tumors of epithelial origin, adrenocortical carcinomas have been described as tumors with a low incidence of telomerase positivity (5). However, no adrenocortical carcinoma ALT cell lines have been reported. H295R is a human cell line that was initially established from an invasive adrenocortical carcinoma $(6,7)$ and has been used as a model for human adrenocortical studies on steroidogenesis (8).

In the literature, ALT cells have been reported to lack telomerase activity and show a great heterogeneity in telomere length within individual cells (9). They often have ALTassociated promyelocytic leukemia (PML) bodies, which contain extra-chromosomal telomeric DNA, specific telomerebinding proteins, and proteins that participate in DNA replication and recombination (10). It has been reported that the recombination event is a leading candidate mechanism for ALT (4), and that the ALT-associated PML bodies are possibly involved in the mechanism by means of telomeric DNA and telomere-binding proteins (11). More recently, 
cyclin D1 overexpression has also been reported to participate in activation of ALT in combination with p53 inactivation in a cancer model using human oral keratinocytes (12). Heterogeneous nuclear ribonucleoproteins (hnRNPs) A2/B1 have reported to be overexpressed in various cancers (13-17), and also have attracted considerable attention as proteins that bind to single-stranded telomeric DNA $(18,19)$. We previously reported that $\mathrm{B} 1$ has stronger affinity for telomeric DNA than A2 and may be an important factor for telomere maintenance (20).

To elucidate the significance and the regulatory factors of ALT in human cancers, we characterized the adrenocortical carcinoma cell line H295R, focusing on its telomere maintenance mechanism. We examined its telomerase activity and telomere length phenotype to demonstrate that H295R is an ALT cell line. Further, we investigated the telomere binding proteins and possible regulatory factors for telomere maintenance in H295R cells.

\section{Materials and methods}

Cell lines and culture conditions. The human adrenocortical carcinoma cell line H295R was purchased from the American Type Culture Collection. As a control for telomerase-positive cells, 293 cells (human embryonic kidney cells transformed with adenovirus 5 DNA, purchased from the Japanese Collection of Research Bioresources) and HeLa cells (human uterine cervical carcinoma cells, JW 36) were used. H295R cells were grown at $37^{\circ} \mathrm{C}$ under $5 \% \mathrm{CO}_{2}$ in Dulbecco's modified Eagle's medium (DMEM)/Ham's F-12 (1:1) supplemented with insulin $(10 \mu \mathrm{g} / \mathrm{ml})$, transferrin $(5.5 \mu \mathrm{g} / \mathrm{ml})$, selenium $(5 \mathrm{ng} / \mathrm{ml})$, linoleic acid $(4.7 \mathrm{ng} / \mathrm{ml})$, bovine serum albumin $(0.5 \mathrm{mg} / \mathrm{ml})$ added in the form of $1 \%$ ITS +1 media (Sigma, St. Louis, MO, USA), 2.5\% fetal bovine serum (FBS), and antibiotics (7). 293 cells and HeLa cells were grown at $37^{\circ} \mathrm{C}$ under $5 \% \mathrm{CO}_{2}$ in DMEM supplemented with $10 \%$ FBS. Sub-confluent cultures were harvested and used for each analysis.

Telomerase assay. Telomerase activity was measured with a PCR-based telomeric repeat amplification protocol (TRAP) method $(21,22)$. Cells $\left(1 \times 10^{6}\right)$ were pelleted, lysed and incubated in $200 \mu 1$ CHAPS lysis buffer on ice for $30 \mathrm{~min}$, and centrifuged before collecting the supernatant. Aliquots of the diluted CHAPS extract $(2 \mu 1)$ containing protein equivalent to $2.5 \times 10^{3}$ or $1 \times 10^{4}$ cells were incubated for $30 \mathrm{~min}$ at $30^{\circ} \mathrm{C}$ in the presence of $50 \mu \mathrm{M}$ deoxynucleotide triphosphates (dNTPs), 10X TRAP buffer, and 20 pmol telomerase substrate (TS) primer (5'-AATCCGTCGAGCAGAG TT-3'). The reaction was digested with $0.15 \mathrm{mg} / \mathrm{ml}$ proteinase $\mathrm{K}$ at $37^{\circ} \mathrm{C}$ for $30 \mathrm{~min}$, extracted with phenol/chloroform (1:1), ethanol precipitated, resuspended in distilled water, and amplified in $20 \mu \mathrm{l}$ of reaction buffer containing $1.5 \mathrm{mM}$ $\mathrm{MgCl}_{2}, 0.1 \mu \mathrm{M}$ of ACX primer [5'-GCGCGG(CTTACC) 3 CTA ACC-3'], and $0.025 \mathrm{U} / \mu 1$ Takara Taq (Takara, Ohtsu, Japan). PCR was performed for 26 cycles at $95^{\circ} \mathrm{C}$ for $30 \mathrm{sec}$ and $62^{\circ} \mathrm{C}$ for $30 \mathrm{sec}$. The amplified products were electrophoresed on a $12.5 \%$ non-denaturing polyacrylamide gel in $0.5 \mathrm{X}$ Tris-borate EDTA buffer, stained with SYBR Green I (Molecular Probes, Eugene, OR, USA), and scanned with
Fluorimager and ImageQuant software (Molecular Dynamics, Sunnyvale, CA, USA). Synthetic telomerase product R8 (5'-AATCCGTCGAGCAGAGTTAG[GGTTAG]7-3') was used as a positive external control, and the 36-bp oligonucleotide TSNT (5'-AATCCGTCGAGCAGAGTTAAAAG GCCGAGAAGCGAT-3'), which is amplified by the TS and a specific NT primer (5'-ATCGCTTCTCGGCCTTTT-3'), was used as a positive internal control. Negative controls included heat-treated $\left(85^{\circ} \mathrm{C}, 10 \mathrm{~min}\right)$ extracts and lysis buffer without extracts.

RNA extraction and reverse transcription-PCR. Total cellular RNA was extracted from collected cells using the Isogen reagent (Nippon Gene, Tokyo, Japan). The RNA $(0.9 \mu \mathrm{g})$ of each cell was used for cDNA production using an RNA PCR kit (Takara) with random nonamers in a total volume of $20 \mu 1$. Aliquots $(1 \mu 1)$ of the reverse transcription products were amplified in $20 \mu \mathrm{l}$ of reaction buffer containing $1.5 \mathrm{mM}$ $\mathrm{MgCl}_{2}, 0.3 \mu \mathrm{M}$ of each primer, and $0.025 \mathrm{U} / \mu 1$ Takara Taq (Takara). The specific primers for the 3 components of the telomerase holoenzyme (hTERT, hTR, and hTEP1), telomere binding proteins (TRF1 and TRF2), and cyclin D1 are shown in Table I, together with their optimal PCR conditions (2,23-26). A competitive multiplex RT-PCR was employed to detect either transcript [a] or [b] of cyclin D1 and to determine their relative levels (26). A shared upstream primer (AL) was used in conjunction with two downstream primers, one specific to transcript [a] (AR), and the other to transcript [b] (BR). The quality of the extracted RNA was controlled using $\beta$-actin mRNA-specific primers (27). The amplified products were electrophoresed on 5\% non-denaturing polyacrylamide gels in $0.5 \mathrm{X}$ Tris-borate EDTA buffer, stained with SYBR Green I, and scanned with Fluorimager and ImageQuant software.

Telomere length analysis. Telomere length was estimated by measurement of the terminal restriction fragment (TRF) length using a modification of Southern blot analysis. Genomic DNA from each cell sample $(10 \mu \mathrm{g})$ was digested with 20 units of RsaI and 20 units of HinfI for $18 \mathrm{~h}$ at $37^{\circ} \mathrm{C}$ to produce the TRFs. The TRFs were resolved on a $0.6 \%$ agarose gel and transferred to a nylon membrane (GeneScreen Plus: PerkinElmer Life Sciences, Boston, MA, USA). The membrane was hybridized with a $5^{\prime}$ end-labeled telomeric probe $\left[\gamma^{-32} \mathrm{P}-\right.$ (TTAGGG) 6 for $16 \mathrm{~h}$ at $65^{\circ} \mathrm{C}$ in hybridization buffer [1 M sodium chloride, $1 \%$ sodium dodecylsulfate (SDS), $10 \%$ dextran] and rinsed in 2X SSC (1X SSC: $150 \mathrm{mM} \mathrm{NaCl}$, $15 \mathrm{mM}$ sodium citrate) with $1 \% \operatorname{SDS}$ for $30 \mathrm{~min}$ at $65^{\circ} \mathrm{C}$ twice. The bound probe was autoradiographed on X-ray film. The TRF signals, which appear as a smear, were divided into 16 equidistant intervals from 1 to 28 kilobase to calculate the mean TRF using the equation TRF $($ mean $)=\left(\mathrm{OD} \hat{\imath} \hat{L}^{\mathrm{L}} \hat{\imath}\right) /(\mathrm{OD} \hat{\imath})$, where $\mathrm{OD} i$ is the signal intensity over interval $i$ and $\mathrm{L} i$ is the kilobase size at the middle of interval $i$.

Pulsed-field gel electrophoresis. Collected cells $\left(1 \times 10^{6}\right)$ were embedded into $1 \%$ agarose plugs and then digested with 50 units of RsaI and 50 units of Hinf I for $18 \mathrm{~h}$ at $37^{\circ} \mathrm{C}$ to produce the TRFs. The TRFs were resolved on a $1 \%$ agarose gel with a CHEF Mapper XA pulsed-field gel electrophoresis system (Bio-Rad, Hercules, CA, USA) in recirculating 
Table I. Oligonucleotides and cycling conditions used for RT-PCR.

\begin{tabular}{|c|c|c|c|}
\hline Oligonucleotides & Temperature $\left({ }^{\circ} \mathrm{C}\right)$; time $(\mathrm{sec})$ & No. of cycles & Refs. \\
\hline hTERT cDNA amplification (145 bp) & $95 ; 25$ & 30 & (23) \\
\hline TERT-1784S; 5'-CGGAAGAGTGTCTGGAGCAA-3' & $68 ; 50$ & & \\
\hline TERT-1928A; 5'-GGATGAAGCGGAGTCTGGA-3' & $72 ; 50$ & & \\
\hline hTR cDNA amplification (125 bp) & $94 ; 40$ & 32 & (2) \\
\hline F3b; 5'-TCTAACCCTAACTGAGAAGGGCGTAG-3' & $60 ; 60$ & & \\
\hline R3c; 5'-GTTTGCTCTAGAATGAACGGTGGAAG-3' & $72 ; 40$ & & \\
\hline hTEP1 cDNA amplification (264 bp) & $94 ; 40$ & 32 & (24) \\
\hline TEP1-S; 5'-TCAAGCCAAACCTGAATCTGAG-3' & $60 ; 60$ & & \\
\hline TEP1-AS; 5'-CCCCGAGTGAATCTTTCTACGC-3' & $72 ; 40$ & & \\
\hline TRF1 cDNA amplification (160 bp) & $95 ; 25$ & 24 & (25) \\
\hline TRF1-S; 5'-GCAACAGCGCAGAGGCTATTATT-3' & $60 ; 50$ & & \\
\hline TRF1-AS; 5'-AGGGCTGATTCCAAGGGTGTAA-3' & $72 ; 50$ & & \\
\hline TRF2 cDNA amplification (93 bp) & $95 ; 25$ & 28 & (25) \\
\hline TRF2-S; 5'-AAACGAAAGTTCAGCCCCG-3' & $60 ; 50$ & & \\
\hline TRF2-AS; 5'-TCCTCCAAGACCAATCTGCTTA-3' & $72 ; 50$ & & \\
\hline \multicolumn{4}{|l|}{ Cyclin D1 cDNA amplification ([a] 448 bp/[b] 275 bp) } \\
\hline AL; 5'-GAACAAACAGATCATCCGCA-3' & $95 ; 30$ & 30 & (26) \\
\hline AR; 5'-AGGGACTGTCATGTGGAGCA-3' & $60 ; 30$ & & \\
\hline \multicolumn{4}{|l|}{ BR; 5'-ATTTCCGTGGCACTAGGTGT-3' } \\
\hline ß-actin cDNA amplification (213 bp) & $95 ; 25$ & 16 & (27) \\
\hline CHO17; 5'-CCCTGAGGCACTCTTCCAG-3' & $60 ; 50$ & & \\
\hline CHO18; 5'-ACTTGCGCTCAGGAGGAGC-3' & $72 ; 50$ & & \\
\hline
\end{tabular}

$0.5 \mathrm{X}$ Tris-borate EDTA buffer at $14^{\circ} \mathrm{C}$. Electrophoresis conditions were $21 \mathrm{~h}$ at $6 \mathrm{~V} / \mathrm{cm}$ with a 5 -sec switch time at an included angle of $120^{\circ}$. The TRFs were transferred to a nylon membrane and hybridized with telomeric probe, as described above.

Fluorescence in situ hybridization (FISH). Cells were arrested in metaphase by colcemid $(0.1 \mu \mathrm{g} / \mathrm{ml})$, treated with $0.075 \mathrm{M} \mathrm{KCl}$ for $15 \mathrm{~min}$ at $37^{\circ} \mathrm{C}$, and fixed and stored in methanol-acetic acid fixative (3:1). Cell suspensions were dropped onto slides and dried overnight at room temperature. After fixation in $4 \%$ formaldehyde in phosphate-buffered saline (PBS: $137 \mathrm{mM} \mathrm{NaCl}, 3 \mathrm{mM} \mathrm{KCl}, 16 \mathrm{mM} \mathrm{Na}_{2} \mathrm{HPO}_{4}$, $2 \mathrm{mM} \mathrm{KHPO}_{4}, \mathrm{pH}$ 7.3) for $5 \mathrm{~min}$, the slides were washed in PBS and treated with pepsin at $1 \mathrm{mg} / \mathrm{ml}$ for $15 \mathrm{~min}$ at $37^{\circ} \mathrm{C}$ at $\mathrm{pH}$ 2.0. After a brief rinse in PBS, the slides were fixed again with formaldehyde and repeatedly washed. To denature the DNA, the slides were heated for $3 \mathrm{~min}$ at $80^{\circ} \mathrm{C}$ in $70 \%$ formamide/2X SSC, then rapidly cooled to $-20^{\circ} \mathrm{C}$ in $70 \%$ ethanol, dehydrated with ethanol, and air-dried. A hybridization mixture containing $70 \%$ formamide, $0.3 \mu \mathrm{g} / \mathrm{ml} \mathrm{FITC-(CCC}$ TAA) $)_{3}$ peptide nucleic acid (PNA) probe (Sawady Inc., Tokyo,
Japan), and 1\% (w/v) blocking reagent (Boehringer-Ingelheim, $\mathrm{GmbH}$, Germany) in $10 \mathrm{mM}$ Tris $\mathrm{pH} 7.2$ was added to the slide. After hybridization for $2 \mathrm{~h}$ at $37^{\circ} \mathrm{C}$, the slides were washed at room temperature with $70 \%$ formamide $/ 10 \mathrm{mM}$ Tris pH 7.2 (2x15 min) and with Tris-buffered saline (TBS: $150 \mathrm{mM} \mathrm{NaCl}, 50 \mathrm{mM}$ Tris, $\mathrm{pH} 7.5)$ containing $0.05 \%$ Tween-20 ( $3 \times 5 \mathrm{~min})$. After being counterstained with propidium iodide $(0.1 \mu \mathrm{g} / \mathrm{ml})$, the slides were embedded with antifade solution (Dabco, Sigma, St. Louis, MO, USA). Images were captured on an Olympus BH-2 microscope with a CoolSNAP cooled CCD camera using RSImage software (Roper Scientific, Tucson, AZ, USA).

Immunoblotting. Immunoblotting analysis with the anti-hnRNP A2 antibody 4G8 and the anti-hnRNP B1 antibody 2B2 was carried out to semi-quantify the amounts of A2 and B1 proteins among the cell lines (28). SDS samples of total cellular lysates containing $50 \mu \mathrm{g}$ of protein were separated by electrophoresis on $12.5 \%$ SDS-polyacrylamide gels (SDS-PAGE). For immunoblotting, proteins were transferred to nitrocellulose membranes (Schleicher \& Schuell, Dassel, Germany) and probed with the anti-A2 and anti-B1 antibodies, 


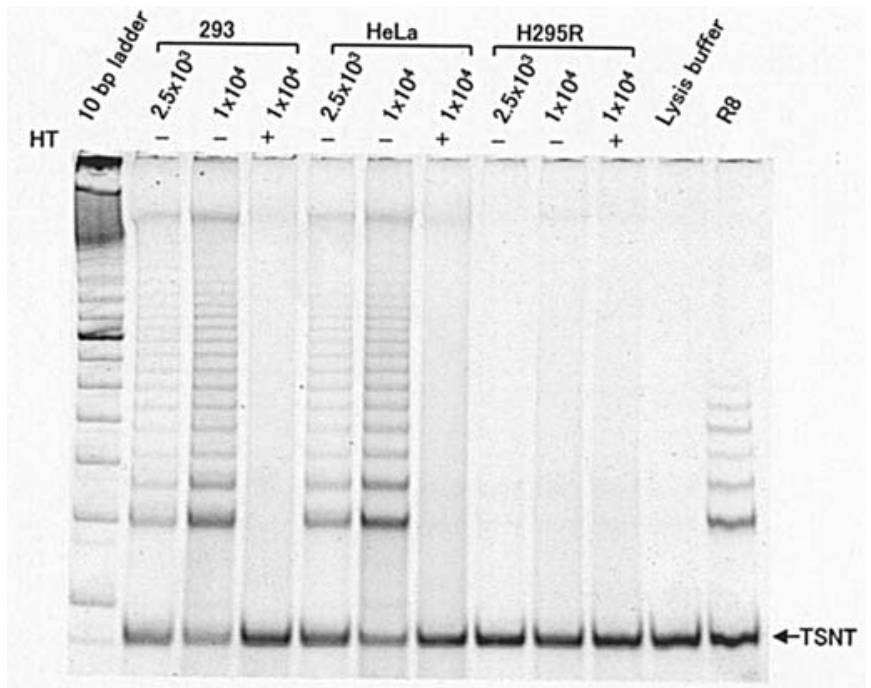

Figure 1. Telomerase activity in cell lines. An amount of CHAPS cell extract equivalent to $2.5 \times 10^{3}$ or $1 \times 10^{4}$ cells from each cell line was used in a PCR-based TRAP assay. Heat-treated (HT) samples and lysis buffer containing no cell extract served as negative controls. TSNT is an internal PCR control to demonstrate the absence of PCR inhibitors in the cell extracts. R8 oligonucleotide (1 amol) is an external intensity standard for PCR amplification. 293 cells and HeLa cells demonstrate varying intensities of 6-bp ladders of PCR products dependent on the equivalent number of cells in the extracts, while H295R cells show no ladders of PCR products.

which were diluted and cocktailed as to produce maximum and specific reactions against both $\mathrm{A} 2$ and $\mathrm{B} 1$ proteins (x1000 dilution for 4G8 and $\mathrm{x} 5000$ dilution for $2 \mathrm{~B} 2$ ). Bound antibodies were detected with peroxidase-conjugated antimouse IgG and Western Lightning Plus chemiluminescence reagent (Perkin-Elmer Life Sciences, Boston, MA, USA).

\section{Results}

Absence of telomerase activity in H295R cells. The telomerase activity of H295R cells was evaluated by testing two protein concentrations equivalent to $2.5 \times 10^{3}$ and $1.0 \times 10^{4}$ cells by the TRAP assay, and compared with those of 293 cells and HeLa cells. Although the samples of 293 cells and HeLa cells produced 6-base incremental ladders of TRAP products, those of H295R cells did not display this characteristic ladder (Fig. 1). The extent of the TRAP signals of 293 cells and HeLa cells were dependent on the protein concentration, indicating that the TRAP assay was performed quantitatively. In H295R cells, potential inhibitors of telomerase were excluded by the dilution of the CHAPS extract, and the presence of the PCR inhibitors could be excluded by amplification of the TSNT internal control.

Suppression of hTERT in H295R cells. The expression of 3 components of the telomerase holoenzyme was estimated by RT-PCR using specific primers to hTERT, hTR, and hTEP1 (Fig. 2a-c). hTERT mRNA was not detected in H295R cells, although it was detected in 293 cells and HeLa cells. In contrast, hTR and hTEP1 mRNA were detected in all cell lines. These results suggested that H295R cells lack telomerase activity due to the absence of hTERT expression.

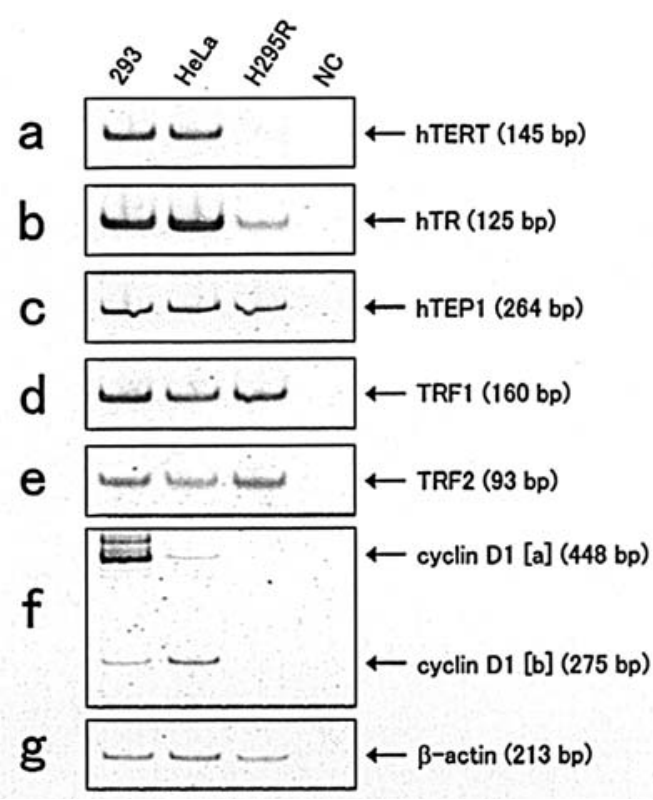

Figure 2. Expression of hTERT (a), hTR (b), hTEP1 (c), TRF1 (d), TRF2 (e) and cyclin D1 (f) mRNAs in cell lines. RNA samples were isolated and examined by RT-PCR. $\beta$-actin mRNA was amplified as the internal standard (g). NC, negative control adding distilled water instead of RNA sample. No products were detected in the negative control reaction for each sample in which reverse transcriptase was omitted (data not shown).

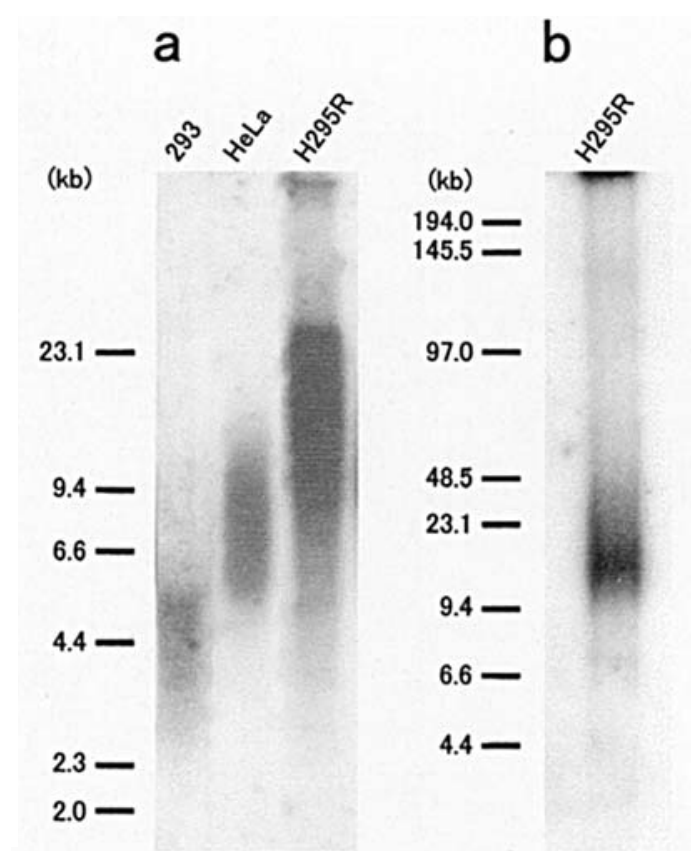

Figure 3. Telomere length analysis of cell lines. (a), Genomic DNA from 293 cells, HeLa cells, and H295R cells was digested with HinfI and RsaI and subjected to TRF electrophoresis on a $0.6 \%$ agarose gel. (b), Genomic DNA from H295R cells was digested with HinfI and RsaI and subjected to TRF pulsed-field electrophoresis on a $1 \%$ agarose gel. The positions of the size markers (in $\mathrm{Kb}$ ) are given on the left.

Long and heterogeneous telomeres in H295R cells. The TRFs of 3 cell lines are shown in Fig. 3.293 cells and HeLa cells had a mean TRF length of $3.7 \mathrm{~kb}$ and $7.2 \mathrm{~kb}$, respectively (Fig. 3a). On the other hand, the TRF length of H295R cells 


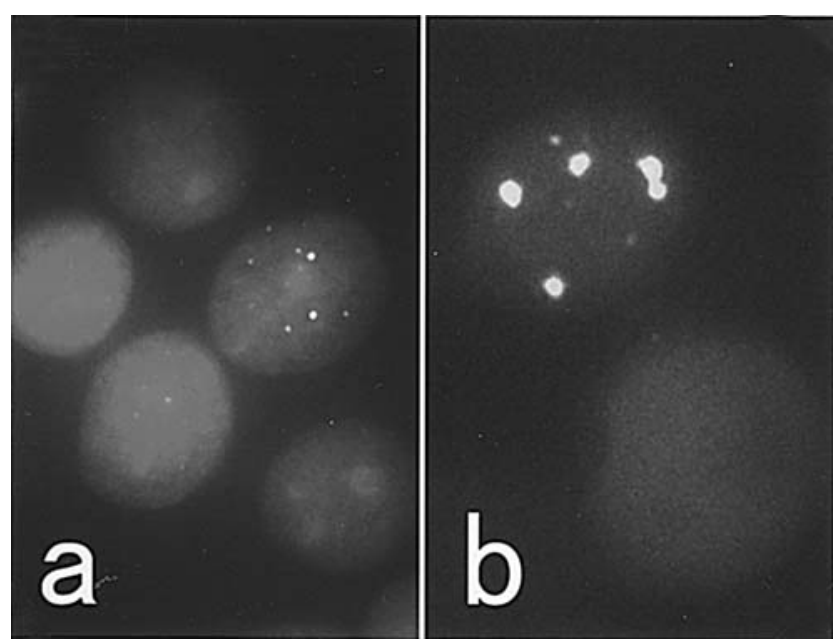

Figure 4. Telomere FISH using an FITC-labeled (CCCTAA)3 PNA probe on H295R cells. (a), Interphase H295R cells demonstrated variability in telomeric signals. (b), An interphase cell displayed large and bright nuclear signals, which presumably represented ALT-associated PML bodies.

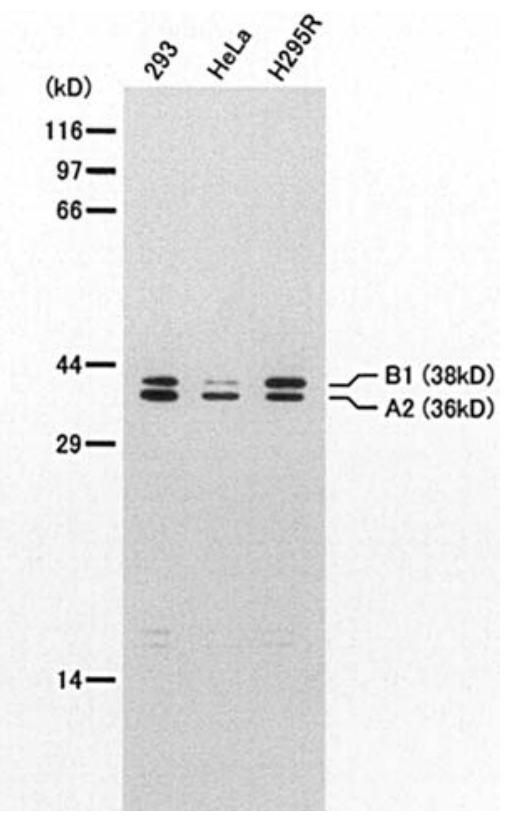

Figure 5. Immunoblot analysis of cell lines with anti-hnRNP A2 and antihnRNP B1 antibodies. Total cellular proteins $(50 \mu \mathrm{g})$ were separated by $12.5 \%$ SDS-PAGE and transferred onto membranes. Immunoblotting using cocktailed anti-hnRNP A2 (4G8) and anti-hnRNP B1 (2B2) antibodies was performed. The positions of the $\mathrm{A} 2$ and $\mathrm{B} 1$ proteins are shown to the right of the figure.

was too long to resolve with a conventional $0.6 \%$ agarose gel, so we carried out pulsed-field electrophoresis on a $1 \%$ agarose gel for H295R cells (Fig. 3b). The TRFs of H295R cells were long and heterogeneous, with a peak around $20 \mathrm{~kb}$, and showed smearing of telomeric DNA up to the well.

Extraordinary signals in telomeres using FISH of H295R cells. FISH demonstrated telomeric spotty signals in interphase nuclei. The signal sizes identified in H295R cells were greatly variable and ranged from undetectable to very large (Fig. 4a). In contrast, telomeric signals were generally very small and faint in 293 cells and HeLa cells (data not shown). In addition, a small population $(<1 \%)$ of $\mathrm{H} 295 \mathrm{R}$ cells displayed large and bright signals, which presumably represented ALT-associated PML bodies (Fig. 4b). These large and bright signals were not found in 293 cells or HeLa cells. Extra-chromosomal telomere-specific signals were not observed in metaphase H295R cells, 293 cells, or HeLa cells.

Expression of telomere-binding proteins and cyclin D1 in H295R cells. The mRNA expression of TRF1 and TRF2 was investigated by RT-PCR, which revealed that both TRF1 and TRF2 were expressed in H295R cells as well as 293 cells and HeLa cells (Fig. 2d and e). Expression of cyclin D1 was also examined by a competitive multiplex RT-PCR (26). Neither transcript [a] nor [b], in which exon 5 is missing, was detected in H295R cells (Fig. 2f). In contrast, both transcript [a] and [b] were expressed in 293 cells and HeLa cells, although their ratios were not the same. Immunoblotting analysis using anti-A2 and anti-B1 antibodies disclosed varied expression levels of $\mathrm{A} 2$ and $\mathrm{B} 1$ proteins among the 3 cell lines (Fig. 5). H295R cells expressed a relatively large amount of $\mathrm{B} 1$ protein, and the ratio of $\mathrm{B} 1$ protein to $\mathrm{A} 2$ in H295R cells (1.37) was estimated at 2-fold that in 293 cells (0.70) and 6-fold that in HeLa cells (0.22).

\section{Discussion}

In this study, we demonstrated that the adrenocortical carcinoma cell line H295R lacks detectable telomerase activity due to loss of hTERT expression. Long and heterogeneous telomeres as well as large nuclear bodies on FISH analysis suggested that H295R cells maintain their telomeres by the ALT mechanism.

The measurement of telomerase activity by the PCRbased assay occasionally gives negative results in telomerasepositive cultured cells. One of the causes of this is the presence of inhibitors of telomerase or Taq polymerase in the cell extracts. In this study, all of the samples were assayed at lower protein levels, because inhibition of telomerase at high protein concentrations has been reported in the TRAP assay. We carried out proteinase digestion and phenol extraction steps after the extension of the TS primer to remove possible inhibitors of Taq polymerase. In addition, an internal standard (TSNT) was used to exclude the inhibitors of Taq polymerase. The second possible cause for a negative result is the presence of telomerase-negative subclones in telomerase-positive cell lines, which results from clonal fluctuations in the levels of telomerase activity (29). For example, telomerase-negative subclones were reported to exist even in 293 cells and HeLa cells (29). This lack of telomerase activity, however, was tentative, and those subclones regained telomerase activity by 18 population doublings. The telomerase activity of H295R cells remained negative at all population doublings, and hTERT expression was not detected on RT-PCR (data not shown). That is, H295R cells are telomerase-negative.

H295R cells were demonstrated to possess long and heterogeneous telomeres, with a peak TRF length around $20 \mathrm{~kb}$. This TRF length and pattern were quite different from those of the telomerase-positive 293 cells $(3.7 \mathrm{~kb}$ ) and HeLa cells $(7.2 \mathrm{~kb})$, but similar to those of reported telomerase- 
negative immortalized cell lines (9). Because their elongated and heterogeneous TRF lengths exceeded the maximum lengths in germ-line tissues $(15 \mathrm{~kb}), \mathrm{H} 295 \mathrm{R}$ cells could be scored as having the ALT telomere phenotype $(9,30)$. Furthermore, the telomere-specific FISH analysis of interphase H295R cells also demonstrated great variability in telomeric signals and large and bright nuclear bodies in a few cells, which are considered to be ALT-associated PML bodies.

Extra-chromosomal telomeric repeat (ECTR) DNA was reported to be found in ALT-associated PML bodies of all ALT cell lines (10) and possibly utilized for telomere maintenance by homologous recombination. ECTR signals could not be detected in metaphase H295R cells. The ECTR DNA is found only in a subset of metaphase cells (10-20\%) in each cell line (31). Because the percentage of interphase H295R cells containing ALT-associated PML bodies was lower than that in reported ALT cells $(<1 \%$ versus $<5 \%)$ (10), ECTR signals in metaphase H295R cells may be also very few and may appear absent.

The ALT cell lines derived from human tumors are mostly of mesenchymal origin $(4,32)$. It is likely that ALT cells are common in specific types of mesenchymal tumors, including glioblastomas (33) and osteosarcomas (30). Possible reasons for the prevalence of ALT in mesenchymal tumors are slower cell turnover and tighter repression of telomerase in mesenchymal cells (4). On the contrary, epithelial cells express low levels of telomerase activity and may already be telomerase competent (5). Epithelial cells are therefore more likely to express or upregulate telomerase at immortalization, and ALT is rare in epithelial carcinomas. However, several types of carcinoma have a relatively low incidence of telomerase positivity. For example, 53\% of thyroid papillary carcinomas did not have detectable telomerase activity (reviewed in ref. 4). The incidence of telomerase positivity is also low in adrenocortical carcinomas, and 2 of the telomerase-negative cases were proved to have the long and heterogeneous ALT phenotype of telomeres (5) like the $\mathrm{H} 295 \mathrm{R}$ cells demonstrated in this study. We propose that ALT is more frequent in endocrine tumors, although further studies are needed to clarify this possibility.

Most ALT cell lines have been derived from in vitro immortalized cells expressing SV40 large T antigen (4), which inactivates the pRB and p53 tumor suppressor pathways (34). Cyclin D1 also inactivates pRB, and unlike SV40 large $\mathrm{T}$ antigen, its overexpression is one of the common genetic alterations in human cancers $(35,36)$. Opitz et al generated an ALT cell line from oral keratinocytes by means of overexpression of cyclin D1 together with a dominantnegative form of p53 (12). In H295R cells, however, the alternatively spliced transcript [a] or [b] of cyclin D1 was not detected. ALT in H295R cells may be achieved by a mechanism other than cyclin D1 overexpression.

ALT is thought to be accomplished by a recombination mechanism, in which telomere DNA-binding proteins such as TRF1 and TRF2 may play an important role. The expression of TRF1 and TRF2 in H295R cells, however, was not significantly different from 293 cells or HeLa cells. hnRNP A2 and B1 are also telomere binding proteins, and are presumably associated with single-stranded telomeric overhangs $(18,19)$. The affinity to telomeric DNA of B1 is stronger than A2 (20). H295R cells showed a higher ratio of hnRNP B1 to A2 than 293 cells and HeLa cells. Interestingly, overexpression of hnRNP B1 is reported in various types of human tumors, such as lung cancers. We propose that hnRNP B1 contributes to the telomere maintenance mechanism including ALT in human cancers.

In conclusion, the adrenocortical carcinoma cell line $\mathrm{H} 295 \mathrm{R}$ is devoid of telomerase activity and maintains its telomeres by the ALT mechanism. Although ALT is detected in in vitro immortalized cells and in some mesenchymal tumors, reports of ALT cell lines derived from human carcinomas were very few until now, consisting of four lung cancer lines $(5,37)$, and one stomach cancer line $(38)$. We anticipate that $\mathrm{H} 295 \mathrm{R}$ cells will be a good model that enables us to understand the mechanism of ALT activation in tumor cells.

\section{Acknowledgements}

We wish to thank Dr S. Kaneko for her interest and useful suggestions. We are also grateful to Ms. R. Totsuka for her excellent technical assistance. This work was supported by the Fund-in-Trust for Cancer Research from the Governor of Ibaraki Prefecture, Japan (to M.F.) and by a Japanese Grantin-Aid for Scientific Research (to H.K.).

\section{References}

1. Shay JW and Bacchetti S: A survey of telomerase activity in human cancer. Eur J Cancer 33: 787-791, 1997.

2. Feng J, Funk WD, Wang SS, Weinrich SL, Avilion AA, Chiu CP, Adams RR, Chang E, Allsopp RC, Yu J, Le S, West MD, Harley CB, Andrews WH, Greider CW and Villeponteau B: The RNA component of human telomerase. Science 269: 1236-1241, 1995.

3. Reddel RR, Bryan TM, Colgin LM, Perrem KT and Yeager TR: Alternative lengthening of telomeres in human cells. Radiat Res 155: 194-200, 2001.

4. Henson JD, Neumann AA, Yeager TR and Reddel RR: Alternative lengthening of telomeres in mammalian cells. Oncogene 21: 598-610, 2002.

5. Bryan TM, Englezou A, Dalla-Pozza L, Dunham MA and Reddel RR: Evidence for an alternative mechanism for maintaining telomere length in human tumors and tumorderived cell lines. Nat Med 3: 1271-1274, 1997.

6. Gazdar AF, Oie HK, Shackleton CH, Chen TR, Triche TJ, Myers CE, Chrousos GP, Brennan MF, Stein CA and La Rocca $\mathrm{RV}$ : Establishment and characterization of a human adrenocortical carcinoma cell line that expresses multiple pathways of steroid biosynthesis. Cancer Res 50: 5488-5496, 1990.

7. Rainey WE, Bird IM, Sawetawan C, Hanley NA, McCarthy JL, McGee EA, Wester R and Mason JI: Regulation of human adrenal carcinoma cell (NCI-H295) production of C19 steroids. J Clin Endocrinol Metab 77: 731-737, 1993.

8. Rainey WE, Bird IM and Mason JI: The H295R cell line: a pluripotent model for human adrenocortical studies. Mol Cell Endocrinol 100: 45-50, 1994.

9. Bryan TM, Englezou A, Gupta J, Bacchetti S and Reddel RR: Telomere elongation in immortal human cells without detectable telomerase activity. EMBO J 14: 4240-4248, 1995.

10. Yeager TR, Neumann AA, Englezou A, Huschtscha LI, Noble JR and Reddel RR: Telomerase-negative immortalized human cells contain a novel type of promyelocytic leukemia (PML) body. Cancer Res 59: 4175-4179, 1999.

11. Dunham MA, Neumann AA, Fasching CL and Reddel RR: Telomere maintenance by recombination in human cells. Nat Genet 26: 447-450, 2000.

12. Opitz OG, Suliman Y, Hahn WC, Harada H, Blum HE and Rustgi AK: Cyclin D1 overexpression and p53 inactivation immortalize primary oral keratinocytes by a telomeraseindependent mechanism. J Clin Invest 108: 725-732, 2001. 
13. Hamasaki M, Kamma H, Wu W, Kaneko S, Fujiwara M, Satoh H, Haraoka S, Kikuchi M and Shirakusa T: Expression of hnRNP B1 in four major histological types of lung cancers. Anticancer Res 21: 979-984, 2001.

14. Tani H, Ohshima K, Haraoka S, Hamasaki M, Kamma H, Ikeda S and Kikuchi M: Overexpression of heterogeneous nuclear ribonucleoprotein B1 in lymphoproliferative disorders: high expression in cells of follicular center origin. Int J Oncol 21: 957-963, 2002.

15. Snead DR, Perunovic B, Cullen N, Needham M, Dhillon DP, Satoh $\mathrm{H}$ and Kamma H: hnRNP B1 expression in benign and malignant lung disease. J Pathol 200: 88-94, 2003.

16. Ohshima K, Karube K, Shimazaki K, Kamma H, Suzumiya J, Hamasaki M and Kikuchi M: Imbalance between apoptosis and telomerase activity in myelodysplastic syndromes: possible role in ineffective hemopoiesis. Leuk Lymphoma 44: 1339-1346, 2003.

17. Satoh H, Kamma H, Ishikawa H, Horiguchi H, Fujiwara M, Yamashita YT, Ohtsuka M and Sekizawa K: Expression of hnRNP A2/B1 proteins in human cancer cell lines. Int J Oncol 16: 763-767, 2000.

18. McKay SJ and Cooke H: A protein which specifically binds to single stranded TTAGGGn repeats. Nucleic Acids Res 20: 1387-1391, 1992.

19. Ford LP, Wright WE and Shay JW: A model for heterogeneous nuclear ribonucleoproteins in telomere and telomerase regulation. Oncogene 21: 580-583, 2002.

20. Kamma H, Fujimoto M, Fujiwara M, Matsui M, Horiguchi H, Hamasaki M and Satoh H: Interaction of hnRNP A2/B1 isoforms with telomeric ssDNA and the in vitro function. Biochem Biophys Res Commun 280: 625-630, 2001.

21. Kim NW, Piatyszek MA, Prowse KR, Harley CB, West MD, Ho PL, Coviello GM, Wright WE, Weinrich SL and Shay JW: Specific association of human telomerase activity with immortal cells and cancer. Science 266: 2011-2015, 1994.

22. Kim NW and Wu F: Advances in quantification and characterization of telomerase activity by the telomeric repeat amplification protocol (TRAP). Nucleic Acids Res 25: 2595-2597, 1997.

23. Ulaner GA, Hu JF, Vu TH, Giudice LC and Hoffman AR: Telomerase activity in human development is regulated by human telomerase reverse transcriptase (hTERT) transcription and by alternate splicing of hTERT transcripts. Cancer Res 58: 4168-4172, 1998.

24. Ramakrishnan S, Eppenberger U, Mueller H, Shinkai Y and Narayanan R: Expression profile of the putative catalytic subunit of the telomerase gene. Cancer Res 58: 622-625, 1998.
25. Yamada K, Yajima T, Yagihashi A, Kobayashi D, Koyanagi Y, Asanuma K, Yamada M, Moriai R, Kameshima $\mathrm{H}$ and Watanabe N: Role of human telomerase reverse transcriptase and telomeric-repeat binding factor proteins 1 and 2 in human hematopoietic cells. Jpn J Cancer Res 91: 1278-1284, 2000.

26. Howe D and Lynas C: The cyclin D1 alternative transcripts [a] and $[\mathrm{b}]$ are expressed in normal and malignant lymphocytes and their relative levels are influenced by the polymorphism at codon 241. Haematologica 86: 563-569, 2001.

27. Kilian A, Bowtell DD, Abud HE, Hime GR, Venter DJ, Keese PK, Duncan EL, Reddel RR and Jefferson RA: Isolation of a candidate human telomerase catalytic subunit gene, which reveals complex splicing patterns in different cell types. Hum Mol Genet 6: 2011-2019, 1997.

28. Kamma H, Satoh H, Matusi M, Wu WW, Fujiwara M and Horiguchi H: Characterization of hnRNP A2 and B1 using monoclonal antibodies: intracellular distribution and metabolism through cell cycle. Immunol Lett 76: 49-54, 2001.

29. Bryan TM, Englezou A, Dunham MA and Reddel RR: Telomere length dynamics in telomerase-positive immortal human cell populations. Exp Cell Res 239: 370-378, 1998.

30. Ulaner GA, Huang HY, Otero J, Zhao Z, Ben-Porat L, Satagopan JM, Gorlick R, Meyers P, Healey JH, Huvos AG, Hoffman AR and Ladanyi M: Absence of a telomere maintenance mechanism as a favorable prognostic factor in patients with osteosarcoma. Cancer Res 63: 1759-1763, 2003.

31. Tokutake Y, Matsumoto T, Watanabe T, Maeda S, Tahara H, Sakamoto S, Niida H, Sugimoto M, Ide T and Furuichi Y: Extra-chromosomal telomere repeat DNA in telomerase-negative immortalized cell lines. Biochem Biophys Res Commun 247: 765-772, 1998.

32. Reddel RR: Alternative lengthening of telomeres, telomerase, and cancer. Cancer Lett 194: 155-162, 2003.

33. Hakin-Smith V, Jellinek DA, Levy D, Carroll T, Teo M, Timperley WR, McKay MJ, Reddel RR and Royds JA: Alternative lengthening of telomeres and survival in patients with glioblastoma multiforme. Lancet 361: 836-838, 2003

34. Bryan TM and Reddel RR: SV40-induced immortalization of human cells. Crit Rev Oncog 5: 331-357, 1994.

35. Motokura T and Arnold A: Cyclins and oncogenesis. Biochim Biophys Acta 1155: 63-78, 1993

36. Hunter T and Pines J: Cyclins and cancer. II: Cyclin D and CDK inhibitors come of age. Cell 79: 573-582, 1994.

37. Saretzki G, Petersen S, Petersen I, Kolble K and von Zglinicki T: hTERT gene dosage correlates with telomerase activity in human lung cancer cell lines. Cancer Lett 176: 81-91, 2002.

38. Kim JH, Lee GE, Kim JC, Lee JH and Chung IK: A novel telomere elongation in an adriamycin-resistant stomach cancer cell line with decreased telomerase activity. Mol Cells 13: 228-236, 2002. 